\title{
Determinants of Profit Growth in Food and Beverage Companies in Indonesia
}

\author{
Endri ENDRI ${ }^{1}$, Aprida Kartika SARI ${ }^{2}$, Yanti BUDIASIH ${ }^{3}$, Tine YULIANTINI ${ }^{4}$, Kasmir KASMIR ${ }^{5}$ \\ Received: September 10, 2020 Revised: November 02, 2020 Accepted: November 16, 2020
}

\begin{abstract}
The study aims to estimate the effect of current ratio (CR), current liability to inventory (CLI), total asset turnover (TAT), net profit margin (NPM), sales growth (SG), and company size (FS) on profit growth (PG). The research population was 18 companies in the Food and Beverage (F\&B) sector listed on the Indonesia Stock Exchange (IDX) from 2014-2018. The data estimation method uses the common effect panel data regression model. The empirical findings show that the CR and CLI ratios have a negative effect on PG, while the TAT, NPM, and SG ratios have a positive effect. Company size is a factor that does not affect the growth of company profits. The results of the study imply that an increase in company profits can be achieved if the company operates efficiently and with low liquidity to encourage higher sales growth. The limitations of the research are as follows: first, this research considers only one type of industry, hence the results of this study would not be the same if applied to another type of industry. Second, the author observes profit growth by using the company's financial ratios and size and ignores other factors that may affect profit growth, for example, the number of employees, total net sales, and market capitalization.
\end{abstract}

Keywords: Profit Growth, Food and Beverage (F\&B) Companies, Indonesia

JEL Classification Code: G23, G30, C33

\section{Introduction}

Current economic conditions can result in a high level of competition in the industrial world. Companies are expected to maintain their business existence by improving their capabilities in various fields. Companies surviving difficult economic conditions are those who have the ability to meet financial obligations and maintain business continuity from time to time.

${ }^{1}$ First Author and Corresponding Author. Associate Professor, Master of Management, Graduate Program, Universitas Mercu Buana, Jakarta, Indonesia [Postal Address: P.O Box. 11650, Jl. Meruya Selatan No.1, Kembangan, Jakarta Barat, Indonesia] Email: endri@mercubuana.ac.id 2Universitas Mercu Buana, Jakarta, Indonesia.

Email: apridakartikasari@gmail.com

${ }^{3}$ Assistant Professor, Institut Teknologi dan Bisnis Ahmad Dahlan, Jakarta, Indonesia. Email: yantibudiasih@yahoo.com

${ }^{4}$ Assistant Professor, Universitas Mercu Buana, Jakarta, Indonesia. Email: tine.yuliantini@mercubuana.ac.id

${ }^{5}$ Associate Professor, Universitas Mercu Buana, Jakarta, Indonesia. Email: kasmirpos@yahoo.com

(c) Copyright: The Author(s)

This is an Open Access article distributed under the terms of the Creative Commons Attribution Non-Commercial License (https://creativecommons.org/licenses/by-nc/4.0/) which permits unrestricted non-commercial use, distribution, and reproduction in any medium, provided the original work is properly cited.
Companies choose the right strategy to be able to improve financial performance. Company performance can affect economic development in Indonesia. The national economy is supported by the manufacturing sector with efforts to foster industrialization and the development of priority products with global competitiveness.

Food and Beverage (F\&B) companies have achieved consistent and positive performance in the F\&B industry, starting from their role in increasing productivity, investment, exports to employment. The Ministry of Industry noted that during 2018 the F\&B industry grew by $7.19 \%$ or exceeded the national economic growth of $5.17 \%$. Furthermore, F\&B companies are one of the sectors that can increase the value of the national investment by contributing up to IDR 56.60 trillion in 2018. The Ministry of Industry stated that Indonesian $\mathrm{F} \& \mathrm{~B}$ products are known to have global competitiveness through their diversity and can make product innovation breakthroughs in meeting the tastes of domestic and foreign consumers.

However, the performance of the F\&B sector during the period 2014 to 2018 experienced a decline in 2015 due to weakening export performance which resulted in a decrease in people's purchasing power. After 2015, the F\&B sector continued to show positive performance driven by positive movements in the domestic tourism sector. 


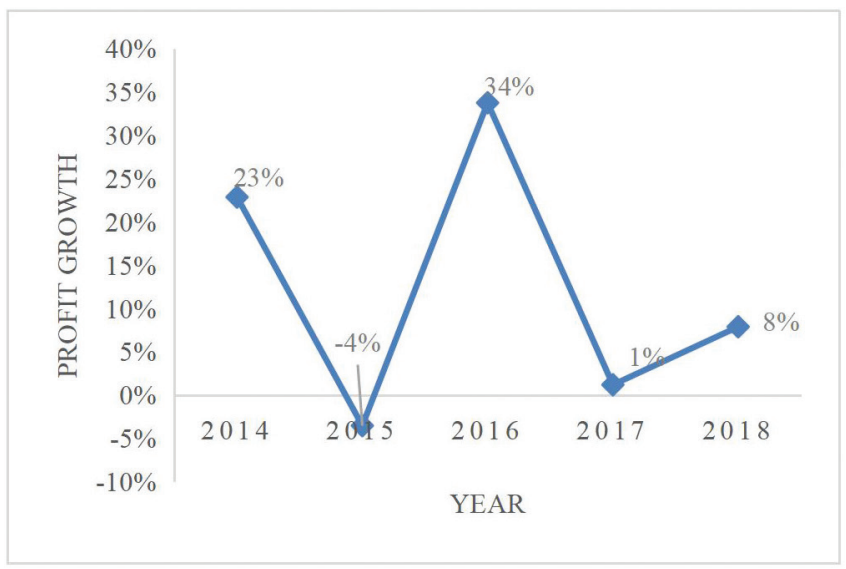

Figure 1: Profit Growth of Food and Beverage Companies

The profit growth of F\&B companies during 2014 - 2018 fluctuated and in 2015 experienced a decline of $4 \%$. The data is obtained from the total net profit of $13 \mathrm{~F} \& \mathrm{~B}$ companies from 18 companies in the F\&B sub-sector listed on the IDX. Even though in 2015 the average value of profit growth decreased significantly, Mayora Indah is a company that had a fairly high-profit growth in 2015 . This was due to the sales growth from the previous year period, a decrease in the cost of goods, and a sufficient gain in exchange rates.

The calculation of profit is done by finding the difference between the income earned by the costs incurred by the company. Companies that get big profits do not necessarily show that the company is working efficiently. Comparing the profit obtained with the wealth or capital used to obtain maximum profit makes the company work efficiently. The company's profit growth is important for internal and external parties to the company. Profit growth can provide a signal that the company's finances are moving positively which will affect firm value. Therefore, the amount of dividends paid by the company in the future will increase each year along with the increase in firm value.

In predicting future profit growth, it is necessary to analyze financial statements through financial ratios. Endri et al. (2020) stated that accounting information regarding the company's operations and the company's financial position can be obtained from financial reports.

Financial ratios are useful for analyzing company performance and company financial condition. Financial ratios are used by company management to compare current ratios and future ratios. As for investors, it is to compare the financial ratios of one company with other similar companies to provide a comparative analysis that shows differences in financial performance. Financial ratios consist of liquidity ratios, solvency ratios, activity ratios, profitability ratios, and growth ratios. The following is the result of the average financial ratio and firm size in the F\&B industry.
Table 1: Average Financial Ratio and Firm Size

\begin{tabular}{|l|c|c|c|c|c|}
\hline Variabel & $\mathbf{2 0 1 4}$ & $\mathbf{2 0 1 5}$ & $\mathbf{2 0 1 6}$ & $\mathbf{2 0 1 7}$ & $\mathbf{2 0 1 8}$ \\
\hline CR (\%) & 189,41 & 207,10 & 233,51 & 238,44 & 266,23 \\
\hline CLI (\%) & 262,22 & 308,89 & 268,86 & 357,16 & 263,40 \\
\hline TAT (\%) & 148,27 & 131,89 & 124,03 & 121,78 & 119,72 \\
\hline NPM (\%) & 6,66 & 6,29 & 9,20 & 8,63 & 8,98 \\
\hline SG (\%) & 32,28 & $-0,16$ & $-2,34$ & 8,54 & 6,58 \\
\hline FS & 24,81 & 24.89 & 23,94 & 24,08 & 24,14 \\
\hline
\end{tabular}

Current Ratio (CR) is a ratio that measures a company's ability to meet short-term debt obligations. Sari et al. (2017) and Siregar \& Batubara (2017) stated that CR does not affect profit growth. However, Warinangin (2015) and Wibisono (2016) showed that CR affects positive profit growth.

Current Liability to Inventory (CLI) is a ratio that measures a company's ability to finance inventory with current debt. The greater the CLI ratio, the greater the need for current debt to finance inventories. Putriana (2016) and Shahnia et al. (2020) stated that the CLI ratio does not affect profit growth. The results of this study differ from the opinion of Anggrainingrum et al. (2019) who stated that CLI has a positive effect on profit growth.

Total Asset Turnover (TAT) is a ratio that measures the efficient use of total assets owned by a company. Sari et al. (2017) showed that the TAT ratio does not affect profit growth. Siregar \& Batubara (2017) also showed that TAT does not affect profit growth. However, these results differ from the results of Megasari et al., (2018) who stated that TAT has a positive effect on profit growth.

Net Profit Margin (NPM) is a ratio to measure the effectiveness of management in managing the company's assets as a whole, which is aimed at the level of profits obtained in relation to sales and investment. Safitri (2016) and Siregar \& Batubara (2017) showed that NPM does not affect profit growth. These results are not in line with the results of Harahap et al., (2020) who stated that NPM has a positive effect on profit growth.

The growth ratio is an indicator for a company that measures the company's ability to maintain its position in the industry and economic development in general. Kajola et al. (2015) stated that sales growth has a negative and insignificant effect on profit growth. These results are not in line with research conducted by Rice (2016) who stated that sales growth has a significant effect on profit growth.

Apart from financial ratios, profit growth can also be influenced by Firm Size (FS). Profit growth can help companies to strengthen the relationship between firm size and the level of profit earned. Companies with growing profits will have a large number of assets, thus providing greater opportunities to generate profitability (Shahnia et al., 2020). 
Endri et al. (2020) stated that FS does not have a significant effect on profit growth. While Olaniyi et al., (2017) stated that FS has a significant positive effect on profit growth.

The purpose of this study was to partially analyze the effect of CR, CLI, TAT, NPM, SG, and FS on profit growth in F\&B companies on the IDX. This study makes four practical contributions. The first is to provide insights and knowledge about the determinants of profit growth of F\&B companies on the IDX. Second, it is useful as a material to predict the performance and condition of the company in the next period. This research can also be used as a reference for improving company performance. Third, it makes it easier for investors to make investment decisions in the future and assess the company's performance in generating profits. Apart from practical contributions, this research also makes theoretical contributions. First, it provides a broader knowledge of information about the determinants of profit growth for academicians. Second, it provides information on the development of theories related to the determinants of profit growth in companies and as a reference for future researchers who will research with similar problems in the future. Third, it provides signals for companies and investors, both positive and negative signals on the company's financial performance, which can be seen from the determinants of profit growth. Fourth, it reduces the information asymmetry that occurs between the principal and agent in disclosing company profits.

\section{Literature Review}

\subsection{Theoretical Framework}

\subsubsection{The Theory of Profit Growth}

Financial management deals with how to obtain the funds needed (financing) at the least possible cost, and how to invest these funds with the most profitable returns (investment). The purpose of establishing a company is to maximize shareholder welfare, by maximizing the value of the company's shares. In financial management, there are several theories that companies can apply to carry out their business activities. However, suitable theories for increasing the profit growth of a company are signal theory and agency theory.

Signal theory is a theory that discusses the ups and downs of prices in the market such as stock prices, bonds, and so on, which will influence investors' decisions. Signal theory involves two parties, namely the internal party consisting of management who acts as the party providing the signal and the external party consisting of investors who act as the party receiving the signal. One of the disclosures of information that can be a signal for investors is the disclosure of company profits. The profits announcement provides a summary of important information regarding the company's financial position and performance for both quarterly and annual periods. Profit announcements submitted by the company can be used as a comparison for investors in making investment decisions and projecting the company's expectations in the future.

Agency problems arise because company owners enter into contracts with company management to manage the company with the aim of maximizing the owner's welfare. Agency theory states that in information asymmetry, management can choose decisions to maximize its interests. Jensen \& Meckling (1976) state that agency theory is a working relationship between the principal (owner) and the agent (manager). As agents, managers are morally responsible for optimizing the principal's profits, and managers are also interested in maximizing their welfare. Therefore, it is likely that the agent does not always act in the best interest of the principal, giving rise to agency problems. One way for management (agents) to make a profit is by manipulating the company's profit figures. The agent's action to maximize his personal interest can result in significant profit growth and is not in accordance with the value of the company's real income.

\subsubsection{Profit Growth}

Operationally, profit is the difference between realized income and costs related to that income. Profit can be viewed as a measure of the efficiency of a company that comes from operational results and non-operational results. Past earnings values that are based on historical costs and current values can be useful for managers in predicting future values. The successful performance of a company can be seen from the increase in profits of the company. The existence of profit growth can indicate that management has succeeded in managing the company's resources effectively and efficiently. Profit growth is the percentage change in the company's profit increase.

In predicting future profit growth, it is necessary to analyze financial statements through financial ratios. Ratio analysis is a financial analysis tool that states a mathematical relationship between two quantities. The objectives of ratio analysis in utilizing financial reports include knowing the company's liquidity and solvency, knowing the effectiveness of the company's operations, and measuring the company's profitability or degree of profit (Endri et al., 2020). The types of financial ratios according to their basic form are grouped into liquidity ratios, solvency ratios, activity ratios, profitability ratios, and growth ratios.

\subsubsection{Financial Ratio}

The liquidity ratio is used to measure the company's ability to meet short-term liabilities by using available current assets. There are several ways to measure the level of a company's liquidity, namely Net Working Capital, CR, and Acid Test Ratio (Quick Ratio). CR is done by measuring 
the company's ability to meet short-term debt using current assets. A high CR indicates higher collateral for short-term debt. The level of CR can be determined by comparing the current assets with current liabilities.

The solvency ratio is the ratio used to measure the extent to which a company is financed with debt. Company solvency is the ability of a company to meet long-term obligations. The solvency ratio consists of CLI, Debt Ratio, Debt to Equity Ratio, and Time Interest Earned Ratio. CLI is the comparison between current debt to inventory. Inventory comes from merchandise or goods that have been purchased by the company to be traded back (Anggrainingrum et al., 2019).

The activity ratio is the ratio used to measure the effectiveness of the company in using its resources. The greater the value of the activity ratio owned, the more effective the company is in managing its resources. Measurement of the activity ratio includes Total Asset Turnover, Fixed Asset Turnover, Inventory Turnover, and Working Capital Turnover. TAT is used to measure the activity and capacity of the company in making sales through the use of company assets and to measure the efficiency of the overall assets owned by the company that has been used to generate income.

Profitability ratios are used to measure management's effectiveness as indicated by the profits generated from sales and company investments. The greater the value of the profitability ratio, the better the company's performance. The profitability ratios consist of Gross Profit Margin, Operating Profit Margin, Net Profit Margin, Return on Investment, and Return on Equity. NPM is the ratio between net profit (net profit), namely sales after deducting all expenses, including taxes, compared to sales. NPM can show the extent to which the company manages its business and controls costs and business volume.

The growth ratio is a ratio used to measure a company's ability to maintain its economic position and industrial growth. The growth ratios consist of asset growth and sales growth. Olaniyi et al. (2017) stated that sales growth has a strategic influence on the company because sales growth is marked by an increase in market share which positively impacts sales of the company and increases the profitability of the company.

In addition to the company's financial ratios, FS can also predict profit growth. FS is used to measure or determine the value and size of a company. The size of the company can affect the value of the company, because the bigger the size of a company, the easier it is for the company to obtain funding sources, both internal and external. Various proxies are used to represent the firm size, namely the number of employees, total assets, total net sales, and market capitalization. Company size can be measured from the total assets owned by the company using the logarithm of total assets.

\subsection{Hypothesis Development}

For this reason, research that is based on the theories previously described and based on the descriptions of previous studies leads to the following research hypothesis statements:

\subsubsection{Current Ration (CR) Affects Profit Growth}

CR can be calculated by dividing current assets by current liabilities. The higher the $\mathrm{CR}$, the greater the company's ability to meet short-term financial obligations. However, the lower the CR, the lower the company's ability to fulfill the short-term financial obligations; hence, the company's stock price decreases (Wibisono, 2016). A high $\mathrm{CR}$ indicates an excess of current assets that are not used in the company's operating activities that generate profits, resulting in low company profitability. In previous research conducted by Wibisono (2016), the results showed that the $\mathrm{CR}$ affects profit growth. But the control variable that is current ratio had the opposite effect on profitability (Nguyen et.al., 2020).

\subsubsection{Current Liability to Inventory (CLI) Affects Profit Growth}

A high CLI indicates a high dependence of the company on suppliers or the greater the company's short-term debt to finance its inventory such that the company's debt burden is getting bigger. This poses a large risk for the company and when the company is unable to pay these obligations at maturity, the company will be faced with large interest expenses that will interfere with the continuity of the company's operations and reduce the profit earned by the company (Putriana, 2016). Anggrainingrum et al. (2019) proved that CLI is proven to affect profit growth.

\subsubsection{Total Asset Turnover (TAT) Affects Profit Growth}

The higher the TAT ratio, the more efficient the use of all assets in generating sales. Efficiency in the use of all assets in generating sales will have an impact on company profits. Thus, the same amount of assets can increase sales volume if the value of TAT is increased (Siregar \& Batubara, 2017). Gladys \& Omagwa (2017) showed that TAT had a positive and significant effect on profit growth.

\subsubsection{Net Profit Margin (NPM) Affects Profit Growth}

NPM shows the company's ability to generate net income against total net sales. The higher the NPM, the more effective and efficient the company is in carrying out its operational activities such that it affects the company's net income. NPM is elastic in terms of profit growth showing 
changes that occur in the independent variable followed by larger changes in the dependent variable (Safitri, 2016). Khaddafi \& Ummah (2014) showed that NPM has a significant effect on profit growth.

\subsubsection{Sales Growth Affects Profit Growth}

Sales growth is the change in total sales or revenue of a company. Revenue includes cash inflows such as cash sales and prospective cash inflows such as credit sales (Rice, 2016). Sales growth reflects past manifestations of investment success and can help predict future profit growth. Sales Growth has a significant effect on Profit Growth according to research conducted by Rice (2016).

\subsubsection{Firm Size (FS) Affects Profit Growth}

FS is one of the factors that influence profit growth. FS can determine whether a company's performance is good in managing its wealth to generate profit (Akinyomi \& Olagunju, 2013). The greater the number of assets owned, the company will be classified as a large company and indicated to have high-profit growth. FS enhances financial performance according to the significant increase in ROA as well as the NPM (Nguyen \& Nguyen, 2020). Inyiama \& Victoria (2014) found that company size has a positive effect on profit growth.

\section{Research Methodology}

\subsection{Research Methods}

Research has been conducted on F\&B sub-sector companies listed on IDX from 2014 to 2018. The data used is the financial reports (secondary data) obtained from www.idx.co.id. The research design used in this research is clausal research which aims to test the hypothesis about the influence of one or more variables (independent variables) on other variables (dependent variable). The dependent variable used is profit growth and the independent variables comprise CR, CLI, TAT, NPM, Sales Growth, and FS. The research sample consisted of 13 companies from the population of $18 \mathrm{~F} \& \mathrm{~B}$ companies listed on IDX from 2014 to 2018.

Sample selection was done by selecting the population using the census method based on the provisions of Sugiyono (2017) who stated that the census method or sampling is saturated, particularly when more population members are used as the sample. The data collection method used in this research is library research. The data analysis method in this study used panel data regression analysis. Microsoft Excel 2016, Eviews 10.0, and SPSS are software used for processing secondary data that has been collected.
Table 2: Operationalization of Variables

\begin{tabular}{|c|c|c|c|}
\hline No. & Variable & Indicator & $\begin{array}{c}\text { Measure } \\
\text { Scale }\end{array}$ \\
\hline \multicolumn{4}{|c|}{ Dependent Variable } \\
\hline 1. & Profit Growth & $Y=\frac{Y_{t}-Y_{t-1}}{Y_{t-1}}$ & Ratio \\
\hline \multicolumn{4}{|c|}{ Independent Variable } \\
\hline 1. & $\mathrm{CR}$ & $\mathrm{CR}=\frac{\text { Current Asset }}{\text { Current Liabilities }}$ & Ratio \\
\hline 2. & CLI & $\mathrm{CLI}=\frac{\text { Current Liabilities }}{\text { Inventory }}$ & Ratio \\
\hline 3. & TAT & TAT $=\frac{\text { Sales }}{\text { Total Asset }}$ & Ratio \\
\hline 4. & NPM & $N P M=\frac{E A T}{\text { Sales }}$ & Ratio \\
\hline 5. & $\begin{array}{l}\text { Sales } \\
\text { Growth (SG) }\end{array}$ & $\begin{array}{l}\text { Sales Growth } \\
=\frac{\text { Sales }_{t}-\text { Sales }_{t-1}}{\text { Sales }_{t-1}}\end{array}$ & Ratio \\
\hline 6. & $\begin{array}{l}\text { Firm Size } \\
\text { (FS) }\end{array}$ & $\begin{array}{l}\text { Firm Size }=\text { Ln (total } \\
\text { asset) }\end{array}$ & Ratio \\
\hline
\end{tabular}

\subsection{Descriptive Statistics}

Descriptive analysis is performed before testing the regression analysis of the data panel, to obtain a thorough overview of the variables used. The measures used in descriptive statistics include frequency, central tendency (mean, median, mode), disperse (standard deviation and variance), coefficients, and correlations between research variables. Descriptive measures are used to represent the characteristics of the location and the full distribution of measurements as a summary value of the existing observed values.

Descriptive analysis in this study includes the mean, median, maximum, minimum, and standard deviation of each research variable. Data processing results using Eviews 10 to obtain descriptive data from research variables for the period 2014-2015 is presented in Table 3.

Table 3 shows statistics on $13 \mathrm{~F} \& \mathrm{~B}$ companies from 2014 to 2018. Standard deviation is a measure to disperse or disseminate data and show fluctuating numbers. The highest standard deviation rate experienced by FS variables was 5.3814 in 2017 . The lowest standard deviation rate experienced by NPM variables was 0.1140 in 2015 . 


\subsection{Panel Data Method}

The approaches that can be used in panel data model analysis are the Common Effect (CE), Fixed Effect (FE), and Random Effect (RE) approaches. The data estimation model was selected using the Chow test, Hausman test, and Lagrange Multiplier test.

\subsubsection{Test Paired Two Models}

\section{a. Uji Chow}

The Chow test is used to choose between the CE model or the FE model for processing (testing) the panel data. Table 4 shows the results of the Chow test using the Likelihood Ratio test on the Eviews application:

It is known that the p-value is $0.6655(>0.05)$, hence H0 is accepted with a $95 \%$ confidence level. This means that the appropriate model to use for panel data testing based on the Chow test results is the $\mathrm{CE}$ model.

\section{b. Uji Hausman}

The Hausman test is a statistical test used to choose between the FE model or RE model for processing (testing) the panel data. Table 5 shows the results of the Hausman test on the Eviews application.

It is known that the p-value is $0.6626(>0.05)$, hence H0 is accepted with a $95 \%$ confidence level. This means that the appropriate model to use for panel data testing based on the Hausman test results is the RE model.

Table 3: Descriptive statistics

\begin{tabular}{|l|c|c|c|c|}
\hline & Mean & Max & Min & $\begin{array}{c}\text { Std. } \\
\text { Dev. }\end{array}$ \\
\hline PL & 0.0331 & 2.0507 & $(2.4494)$ & 0.7647 \\
\hline CR & 2.2694 & 8.6378 & 0.5139 & 1.7184 \\
\hline CLI & 2.9351 & 20.435 & 0.4756 & 3.2312 \\
\hline TAT & 1.2915 & 3.1048 & 0.2363 & 0.6497 \\
\hline NPM & 0.0795 & 0.3897 & $(0.2398)$ & 0.1140 \\
\hline SG & 0.0898 & 3.0504 & $(0.9999)$ & 0.4258 \\
\hline FS & 24.372 & 30.498 & 14.558 & 5.3814 \\
\hline
\end{tabular}

Table 4: Chow Test

\begin{tabular}{|l|c|c|c|}
\hline Effects Test & Statistic & d.f. & Prob. \\
\hline Cross-section F & 0.782092 & $(12,46)$ & 0.6655 \\
\hline $\begin{array}{l}\text { Cross-section } \\
\text { Chi-square }\end{array}$ & 12.068502 & 12 & 0.4402 \\
\hline
\end{tabular}

\section{c. Uji Lagrange Multiplier (LM)}

The Lagrange Multiplier (LM) test is a statistical test used to choose between the CE model or the RE model for processing (testing) the panel data. Table 6 shows the results of the LM test on the Eviews application:

Table 6 presents it is known that the p-value of the F-Statistical Test is $0.6655(>0.05)$ so that $\mathrm{H} 0$ is accepted with a $95 \%$ confidence level. This means that the appropriate model to use for panel data testing based on the Chow test results is the CE model. Based on the test results of the three-panel data regression models, it can be concluded that the panel data regression model that can be used is the CE model.

\subsubsection{Common Effect (CE) Model with White- Heteroskedasticity}

The CE model applied in this study is a model that eliminates the problem of heteroscedasticity by strengthening the residuals using white-heteroscedasticity. The results of panel data regression estimation using the $\mathrm{CE}$ model with white-heteroscedasticity are shown in Table 7 as follows:

Based on the test results shown in Table 7, the panel data regression equation used in this study is as follows:

$$
\begin{aligned}
P L_{\mathrm{it}}= & -0.252867-0.065086 C R_{i t}-0.026964 C L I_{i t} \\
& +0.114464 T A T_{i t}+2.275894 N P M_{i t}+0.272899 S G_{i t} \\
& +0.010175 F S_{i t}
\end{aligned}
$$

From the panel data regression equation used in this study, it can be interpreted as follows:

- A constant with a value of -0.252867 indicates all independent variables are equal to zero.

- CR coefficient of -0.065086, which means that CR has a negative effect on Profit Growth.

Table 5: Hausman Test

\begin{tabular}{|l|c|c|c|}
\hline Test Summary & $\begin{array}{c}\text { Chi-Sq. } \\
\text { Statistic }\end{array}$ & $\begin{array}{c}\text { Chi-Sq. } \\
\text { d.f. }\end{array}$ & Prob. \\
\hline $\begin{array}{l}\text { Cross-section } \\
\text { random }\end{array}$ & 4.103770 & 6 & 0.6626 \\
\hline
\end{tabular}

Table 6: Lagrange Multiplier Test

\begin{tabular}{|l|c|c|c|}
\hline & \multicolumn{3}{|c|}{ Test Hypothesis } \\
\hline & Cross-section & Time & Both \\
\hline Breusch-Pagan & 0.695572 & 0.215028 & 0.910601 \\
\hline & $(0.4043)$ & $(0.6429)$ & $(0.3400)$ \\
\hline
\end{tabular}


Endri ENDRI, Aprida Kartika SARI, Yanti BUDIASIH, Tine YULIANTINI, Kasmir KASMIR I

Table 7: Conclusion Testing Panel Data Method

\begin{tabular}{|l|c|c|c|c|}
\hline Variable & Coefficient & Std. Error & t-Statistic & Prob. \\
\hline C & -0.252867 & 0.261879 & -0.965588 & 0.3383 \\
\hline CR & -0.065086 & 0.020436 & -3.184906 & 0.0023 \\
\hline CLI & -0.026954 & 0.006233 & -4.325959 & 0.0001 \\
\hline TAT & 0.114464 & 0.048970 & 2.337418 & 0.0229 \\
\hline NPM & 2.275896 & 0.792692 & 2.871094 & 0.0057 \\
\hline GS & 0.272899 & 0.122502 & 2.227718 & 0.0298 \\
\hline FS & 0.010175 & 0.012368 & 0.822678 & 0.4141 \\
\hline R-squared & 0.250248 & Mean dep. Var & & 0.192098 \\
\hline Adjusted R-squared & 0.172688 & S.D. dep. Var & 0.751950 \\
\hline S.E. of regression & 0.651133 & Sum squared resid & 24.59049 \\
\hline F-statistic & 3.226487 & D-W stat & 2.194036 \\
\hline Prob(F-statistic) & 0.008372 & & \\
\hline
\end{tabular}

- CLI coefficient of -0.026964 , which means that CLI has a negative effect on Profit Growth.

- TAT coefficient of 0.114464 , which means that TAT has a positive effect on profit growth.

- NPM coefficient of 2.275894, which means that NPM has a positive effect on profit growth.

- GS coefficient of 0.272899 , which means that PP has a positive effect on Profit Growth.

- FS coefficient of 0.010175 , which means that FS has a positive effect on profit growth.

The results of the feasibility test of the model using the coefficient of determination (R2) produce a value of 0.250248 or $25 \%$, so all independent variables used in the research model can explain the fluctuations in changes in profit growth by $25 \%$. Meanwhile, $75 \%$ is explained by other variables that are not included in the model being tested.

Table 7 presents that the F-count value is 3.226487 with a prob. value of 0.008372 . This shows that F-count $>$ F-table $(3.226487>2.26)$ with a prob. value $(0.008372<0.05)$. Therefore, it can be concluded that research in the F\&B sector for the period 2014-2018 using independent variables including CR, CL, TAT, NPM, SG, and FS simultaneously have a significant effect on profit growth (dependent variable). However, partially it can be seen that the effect of the independent variables on the dependent variable is as follows:

- $\mathrm{CR}$ has a negative $\beta$ coefficient value of -0.065086 with a prob. value $(0.0023<0.05)$.

- CLI has a negative $\beta$ coefficient value of -0.026964 with a prob. value $(0.0001<0.05)$.
- TAT has a positive $\beta$ coefficient value of 0.114464 with a prob. value $(0.0229<0.05)$.

- NPM has a positive $\beta$ coefficient value of 2.275894 with a prob. value $(0.0057<0.05)$.

- Sales Growth has a positive $\beta$ coefficient value of 0.272899 with a prob. value $(0.0298<0.05)$.

- Firm size has a positive $\beta$ coefficient value of 0.010175 with a prob. value $(0.4141>0.05)$.

Based on these results, it shows that the variables CR, CLI, TAT, NPM, and Sales Growth affect profit growth, while FS does not affect profit growth.

\section{Discussion}

\subsection{The Effect of Current Ratio (CR) on Profit Growth}

Empirical findings prove that the $\mathrm{CR}$ ratio has a negative effect on profit growth, meaning that an increase in the CR ratio will lead to a decrease in profit growth. The company's ability to fulfill its short-term obligations is not in line with the company's ability to create the desired profit growth. High CR can be caused by the ineffective management of cash, inventories, and accounts receivable. Companies that are considered too liquid will have a negative impact on company performance because management cannot utilize their productive assets, which will result in costs for the company and result in decreased profits. Signal theory explains that high CR information can mean a negative signal for the sustainability of investments made by investors, because, the higher the CR, the lower the profit growth. 
These results are the same as Niresh (2012), Khidmat \& Rehman, (2014), Endri et al. (2020), and Shania et al. (2020) who concluded that $\mathrm{CR}$ affects profit growth.

\subsection{The Effect of Current Liabilities to Inventory (CLI) on Profit Growth}

The results showed that the CLI ratio has a negative effect on profit growth. This shows that the greater the CLI ratio, the lower the profit growth. A high CLI ratio indicates a company's high dependence on suppliers or an increased level of short-term debt to finance supplies. A high increase in debt levels can pose a risk if the company fails to meet its obligations at maturity, thus impacting the company's operational sustainability. Besides, the company bears a high-interest expense, thereby reducing the company's profit. This means that the company cannot use its debt to make a profit. The results of this study are in accordance with Saleem \& Rehman (2011), Ajanthan (2013), Priya \& Nimalathasan (2013), and Anggrainingrum et al. (2019) who concluded that CLI affects profit growth.

\subsection{The Effect of Total Asset Turnover (TAT) on Profit Growth}

Empirical evidence shows that the TAT ratio has a positive effect on profit growth. These findings indicate that the TAT ratio describes the level of efficiency of a company in using its assets to generate sales. The faster the assets turnover, the greater the income generated and will affect profit growth. This is also supported by signal theory, if the TAT of an F\&B company increases, the resulting profit will also be high and provide a positive signal related to the company's financial performance. The results of this study support the research findings of Putriana (2016), Megasari et al. (2018), and Harahap et al. (2020).

\subsection{The Effect of Net Proft Margin (NPM) on Profit Growth}

Empirical evidence shows that an increase in the NPM ratio can increase company profit growth. NPM ratio shows the proportion of the company's profit to its net sales. The NPM ratio is used to measure the level of management efficiency in managing the company and predict future profitability. The increase in the NPM ratio means that the company can increase its business by achieving operating profit in that period. A high NPM ratio shows that the more efficient the costs incurred, the greater the level of net income. With the achievement of this profit, investors get useful information related to company performance and have high expectations of return on capital. In other words, it can be said that profit growth will also increase. The research findings are in accordance with Putriana (2016), and Purwanto \& Bina (2016) who stated that the NPM ratio affects profit growth.

\subsection{The Effect of Sales Growth on Profit Growth}

Based on the research results, sales growth has a positive effect on profit growth. This shows that income is the cash inflow obtained from the company's ongoing business activities. The company can obtain a higher rate of profit growth without accumulating external capital if its sales growth and internal growth increases. Companies that experience an increase in the level of sales from one period to the next, which are encouraged or supported by effectiveness in managing sales, can increase profits. The F\&B companies studied were able to manage sales and earn profits, both from service, during, and after-sales, such as minimizing warranty costs by minimizing defective products. The empirical findings of this study provide the same evidence as Jang \& Park (2011), Rice (2016,) and Siregar \& Batubara (2019) who stated that sales growth affects profit growth.

\subsection{The Effect Firm Size (FS) on Profit Growth}

The FS variable is one factor that does not affect profit growth. Companies that have small total assets will find it more difficult to generate profits, but companies that have large FS do not necessarily have large profits. This is because companies that have large assets have the potential to have large expenses and this will reduce the resulting profit. In this study, it can be said that FS does not support profit growth. The results of the study are in line with Akbas \& Karaduman (2012) and Vu et al. (2019) who stated that FS cannot affect profit growth.

\section{Conclusions}

This study aims to estimate the effect of CR, CLI, TAT, NPM, Sales Growth, and FS on profit growth. The empirical findings of this study prove that CR, CLI, and sales growth ratios have a negative effect on profit growth. The TAT and NPM ratios have a positive effect on profit growth. FS is the only factor that does not affect the growth of company profits.

Based on the results of research and discussion known limitations of the research are as follows: first, this research considers only one type of industry, namely the F\&B sub-sector, hence the results of this study would not be the same if applied to another type of industry. Second, the observed research period is limited because it only covers 2014-2018. Third, the author observes profit growth by using the company's financial ratios and size and ignores other factors that may affect profit growth, for example, the number of employees, total net sales, and market capitalization. 
Therefore, the suggestions that can be conveyed in this study include: companies engaged in the F\&B sub-sector must pay more attention to the performance and ability in managing CR and CLI. This is because if the company's liquidity and solvability are low, it will have an impact on profit growth and this condition will affect the company's internal funding sources.

Besides, companies need to pay attention to the value of TAT, NPM, and the company's sales growth in disclosing profit growth. The higher these values, the easier the company will make decisions to obtain and predict future profit growth.

Investors are advised to make an investment decision after observing the company's financial performance. In this study, it shows that companies with high TAT, NPM, and sales growth values mean a positive signal for investors in making investment decisions, while companies with high $\mathrm{CR}$ and CLI values mean a negative signal for investors in making investment decisions. For further research, it is recommended that research be conducted on other sector companies with different research years and use other independent variables to provide another picture of the determinants of profit growth

\section{References}

Akinyomi, O.J., \& Olagunju, A. (2013). Effect of firm size on profitability: Evidence from Nigerian Manufacturing sector. Prime Journal of Business Administration and Management, 3(9), 1171-1175.

Akbas, H. E., \& Karaduman, H. A. (2012). The effect of firm size on profitability: An empirical investigation on Turkish manufacturing companies. European Journal of Economics, Finance and Administrative Sciences, 55, 21-27.

Ajanthan, A. (2013). Nexus between liquidity and profitability: A study of trading companies in Sri Lanka. European Journal of Business and Management, 6(7), 47-63

Anggrainingrum, D., Malavia R., \& Salim, M.A. (2019). The effect of working capital to total asset, current liability to inventory, operating income to total liabilities, \& gross profit margin on profit growth (studies on food and beverage manufacturing companies listed on the Indonesia Stock Exchange 2013 2016). e-Jurnal Riset Manajemen, 8(7), 23-38

Endri, E., Susanti, D., Hutabarat, L., Simanjuntak, T.P. \& Handayani, S. (2020). Financial performance evaluation: Empirical evidence of pharmaceutical companies in Indonesia. Systematic Reviews in Pharmacy, 11(6), 803-816. https://doi. org/10.31838/srp.2020.6.117.

Gladys, M., \& Omagwa, J. (2017). Asset structure and financial performance: A case of the Nairobi securities exchange, Kenya. Research Journal of Finance and Accounting, 8(4), 192-200.

Harahap, I. M., Septiania, I., \& Endri, E. (2020). Effect of financial performance on firms' value of cable companies in Indonesia.
Accounting, 6(6), 1103-1110. https://doi.org/10.5267/j.ac.2020. 7.008 .

Inyiama, O. I., \& Victoria, N. C. (2014). An empirical investigation of the interactions between firm size and firm's financial performance: A study based on the brewery sector of Nigeria. Journal of Finance and Bank Management, 2(3-4), 53-68.

Jang, S., \& Park, K. (2011). Inter-relationship between firm growth and profitability. International Journal of Hospitality Management, 30(4), 1027-1035. https://doi.org/10.1016/j. ijhm.2011.03.009

Jensen, M. C. \& Meckling, W. H. (1976). Theory of the firm: Managerial behavior, agency costs, and ownership structure. Journal of Financial Economics, 3, 305-360.

Kajola, S. O., Adewumi, A. A., \& Oworu, O. O. (2015). Dividend pay-out policy and firm financial performance: Evidence from Nigerian listed non-financial firms. International Journal of Economics, Commerce and Management, 3(4), 1-12.

Khaddafi, M., \& Ummah, A. (2014). Influence analysis of Return on Assets (ROA), Return on Equity (ROE), Net Profit Margin (NPM), Debt to Equity Ratio (DER), and Current Ratio (CR), against corporate profit growth in automotive in Indonesia stock exchange. International Journal of Academic Research in Business and Social Sciences, 4(12), 101-114.

Khidmat, W., \& Rehman, M. (2014). Impact of liquidity and solvency on the profitability chemical sector of Pakistan. Economics Management Innovation, 6(3), 34-67

Megasari, R. A.W. S., Surtikanti, T., \& Darmansyah, A. (2018). Determinan of profit growth for manufacturing companies on Indonesia stock exchange. Jurnal Riset Akuntansi dan Perpajakan, 5(2), 166-174.

Niresh, A. (2012). The trade-off between liquidity and profitability: A study of selected manufacturing firms in Sri Lanka. Journal of Arts, Science, and Commerce, 4(2), 1-34

Nguyen, A. H., Pham, H.T., \& Nguyen, H.T. (2020). Impact of Working Capital Management on Firm's Profitability: Empirical Evidence from Vietnam. Journal of Asian Finance, Economics, and Business, 7(3), 115-125. https://doi.org/10.13106/jafeb. 2020.vol7.no3.115.

Olaniyi, C.O., Olayemi, O.S., Obembe, B.O., \& Bolarinwa, S.T. (2017). Re-examining firm size-profitability nexus: Empirical evidence from non-financial listed firms in Nigeria. Global Business Review, 18(3), 543-558. https://doi. org/10.1177/0972150917692064

Priya, K., \& Nimalathasan, B. (2013). Liquidity management and profitability: A case study of listed manufacturing companies in Sri Lanka. International Journal of Technological Exploration and Learning, 2(4), 135-151

Purwanto, A., \& Bina, C. R. (2016). Analysis of financial ratio towards earning growth in mining companies. Universal Journal of Industrial and Business Management, 4(3), 81-87, https://doi.org/10.13189/ujibm.2016.040301.

Putriana, M. (2016). Factors affecting growth. Jurnal Ilmiah Ekonomi dan Bisnis (Eksis), 7(1), 53-68. 
Rice, A. (2016). Analysis of factors affecting profit growth with company size as a moderating variable in manufacturing companies listed on the Indonesia stock exchange. Jurnal Wira Ekonomi Mikroskil, 6 (1), 85-101.

Safitri, I. L. K. (2016). The effect of financial ratios on profit growth in manufacturing companies in the consumer industry sector that are listed on the Indonesia stock exchange (Case Study at Kalbe Farma Tbk Company 2007-2014 period). Jurnal Akuntansi dan Bisnis, 2(2), 137-158.

Saleem, Q., \& Rehman, R. (2011). Impacts of liquidity ratios on profitability, interdisciplinary. Journal of Research in Business, 1(7), 78-91

Sari, D. P., Paramu, H., \& Utami, E. S. (2017). Analysis of the effect of financial ratios and asset size on profit growth of manufacturing companies listed on the Indonesia stock exchange 2010-2013. Jurnal Ekonomi Bisnis dan Akuntansi, 6(1), 63-66.

Shahnia, C., Purnamasari, E.P., Hakim, L., \& Endri, E. (2020). The determinant of profitability: Evidence from trading, service, and investment companies in Indonesia. Accounting, 6(5), 787-794. https://doi.org/10.5267/j.ac.2020.6.004
Siregar, Q., \& Batubara, H. (2017). Analysis of the determinants of profit growth on the Indonesia stock exchange. Jurnal Riset Finansial Bisnis, 1(1), 79-92. https://doi.org/10.5281/ zenodo.10491.

Sugiyono. (2017). Quantitative research methods, qualitative, and $R \& D$. Bandung: Alfabeta, $\mathrm{CV}$

Nguyen, T. N. L., \& Nguyen, V. C. (2020). The determinants of profitability in listed enterprises: A study from the Vietnamese Stock Exchange. Journal of Asian Finance, Economics, and Business, 7(1), 47-58. https://doi.org/10.13106/jafeb.2020. vol7.no1.47.

Vu. V. T. T., Do, N. H., Dang, H. N., \& Nguyen, T. N. (2019). Profitability and the distance to default: Evidence from the Vietnam securities market. Journal of Asian Finance, Economics, and Business, 6(4), 53-63. https://doi.org/10.13106/ jafeb.2019.vol6.no4.53

Wibisono, S.A. (2016). The effect of financial performance on profit growth in automotive companies on the IDX. Jurnal Ilmu dan Riset Manajemen, 5(12), 1-24 